- perpendicular magnetic field. When they set the field in one direction, electrons are steered away from the positive bottom deck and flow freely. When the magnetic field is flipped, the electrons crash into the lower deck and recombine with the holes - effectively turning the switch off (see 'Magnetic lock').

The ability of a magnetic logic gate to hold the switch on or off without a voltage "could lead to great reduction of energy consumption", says study co-author Jin Dong Song, a physicist at KIST. Even more impressively, the magnetic switches "can be handled like software", he says, by simply flipping the field to enable or disable a circuit. Thus a mobile phone could, for example, reprogram a bit of its microcircuitry to process video while its user watched a clip on YouTube, then switch the chip back to signal processing to take a phone call. This could greatly reduce the volume of circuitry needed inside the phone.

Such reconfigurable logic could be invaluable in satellites, adds Mark Johnson of the Naval Research Laboratory in Washington DC, a co-author of the paper. If part of a chip failed in orbit, another sector could simply be reprogrammed to take over. "You've healed the circuit and you've done it from Earth," he says.

To really catch on, however, the magnetic logic would have to be integrated with existing silicon-based technologies. That may not be easy. For one thing, indium antimonide, the semiconductor crucial to the circuits, doesn't lend itself well to manufacturing processes used to make modern electronics, according to Junichi Murota, a researcher working with nanoelectronics at Tohoku University in Japan. But Johnson says that it may eventually be possible to build similar bridges with silicon.

Integrating the miniature magnets needed to control the devices into a normal chip wouldn't be easy either. Companies should be able to solve these challenges, but only if they decide the devices are worthwhile, says Salis. At the moment, he adds, it is not clear whether the devices will perform well at the sizes needed for a practical chip - much smaller than the micrometre dimensions of the prototypes.

But Johnson notes that magnetism is already catching on in circuit design: some advanced devices are beginning to use a magnetic version of random access memory, a type of memory that has historically been built only with conventional transistors. "I think a shift is already under way," he says. .

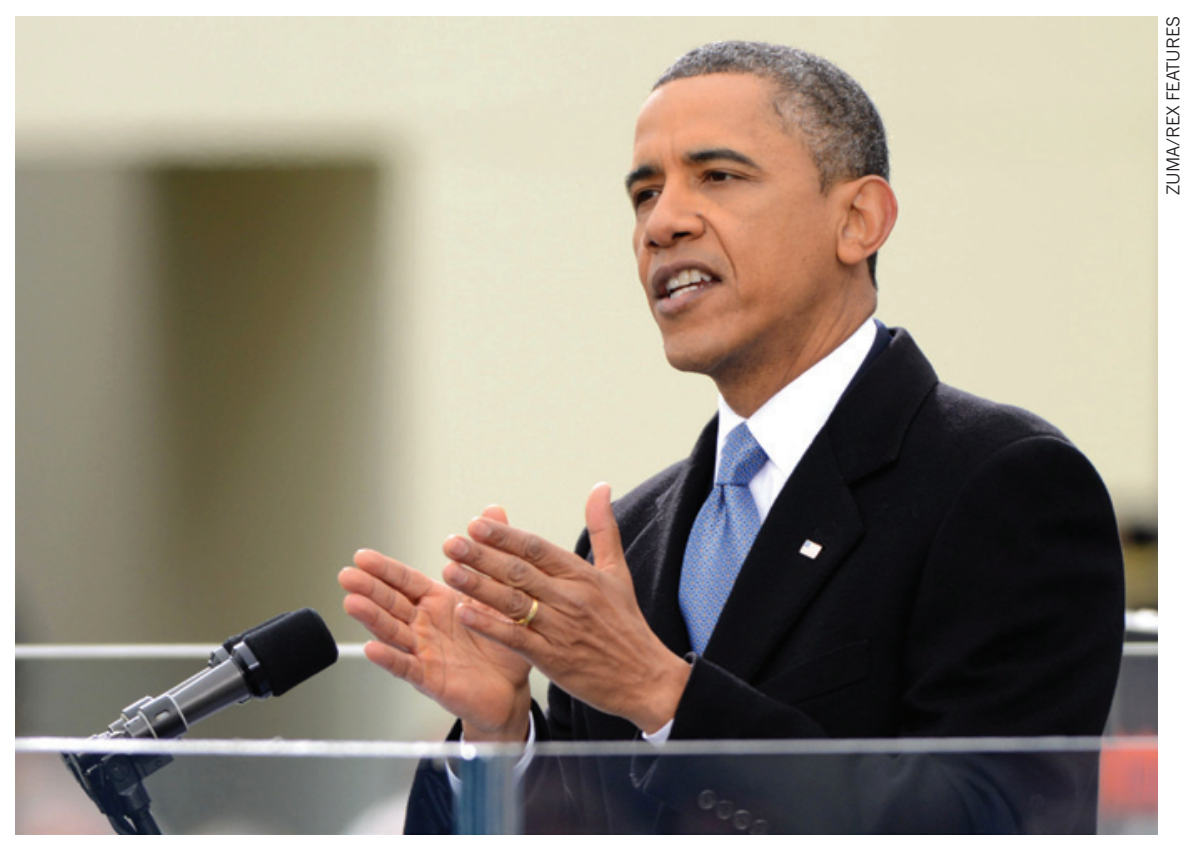

US President Barack Obama reinforced environment promises in his second inaugural address.

ENVIRONMENT

\title{
Obama rekindles climate hopes
}

\section{President will use regulations to sidestep stalled Congress.}

\section{BY JEFF TOLLEFSON}

卫 Throughout his re-election campaign, US President Barack Obama rarely said the words 'climate change'. But in his second inaugural address, on 21 January, Obama renewed a commitment to address global warming, citing both moral and economic imperatives. To fail, he said, "would betray our children and future generations".

The 2010 demise of a climate bill that would have enacted a cap-and-trade system to limit greenhouse-gas emissions remains one of the key failures of Obama's first term. With a divided Congress still standing in the way of legislation, the administration is likely to rely on its own power to impose new regulations, once Obama has replaced the retiring heads of three agencies key to the climate agenda (see 'Climate team change').

As proof of what is possible, Obama can point to a welcome, if unexpected, reduction in US greenhouse-gas emissions during his first term. The decline is in part a result of the economic slowdown and a shift in electricity production from coal to natural gas, which has become cheap and plentiful in recent years. But policies have helped. These include federal greenhouse-gas standards for vehicles, and the introduction by more than half of the states of significant energy and climate initiatives that could deliver further

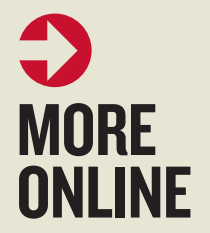

\section{TOP STORY}

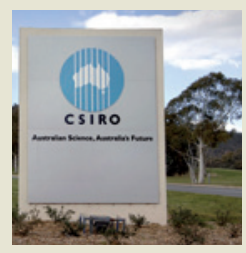

Australian research agency raises ongoing questions on alleged bullying go.nature.com/squzlk

\section{MORE NEWS}

- Small oil spills may actually be bigger than originally thought go,nature. com/a64awg

- Ageing causes poor sleep and impairs memory go.nature.com/hppcay - Aphrodisiac craze endangers Himalayan caterpillar go.nature.com/yegirz

\section{SLIDESHOW}

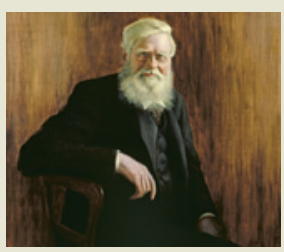

Letters of Alfred Russel Wallace go online go.nature.com/ jepahh 
reductions - perhaps even the $17 \%$ cut by 2020 that Obama promised at the United Nations climate summit in Copenhagen in 2009.

Many see the reductions as an opportunity. They "should give Americans confidence that climate policies can be effective", says Paul Bledsoe, an environmental consultant in Washington DC and a White House climatechange official under former president Bill Clinton.

As a next step, Obama's administration is expected to impose two greenhouse-gas regu갈 lations targeted at power plants, which are responsible for roughly $40 \%$ of US emissions. The first, proposed last year by the Environmental Protection Agency but not yet finalized, would limit emissions from new plants, effectively banning the construction of coalfired plants that are not equipped to capture and sequester carbon dioxide.

A second rule, not yet released, could set emissions limits for existing plants, encouraging the shift towards natural gas. Other rules could target the oil and gas industry by limiting emissions from refineries and drilling sites.

But these piecemeal regulatory efforts will not be sufficient to reduce emissions by $83 \%$ by mid-century - a target promised by Obama at the Copenhagen talks. One question is whether the president can build support for a broad programme of energy research and - development that could drive down the cost of 줄 large-scale, low-carbon energy, and ultimately make a carbon tax or a cap-and-trade agreement politically palatable.

The President's Council of Advisors on Science and Technology has recommended increasing spending on energy research and development from around US $\$ 4$ billion per year to $\$ 16$ billion, and some organizations have advocated even more. Armond Cohen, executive director of the Clean Air Task Force in Boston, Massachusetts, argues that Obama could attract conservative support for a strategic research programme focused on large-scale energy technologies such as carbon capture and storage methods and advanced nuclear reactors. Such a programme might look like the energy department's Advanced Research Projects Agency-Energy, itself inspired by a similar defence-department programme, says Cohen. Once technologies are developed, government agencies could use their buying power to expand production and reduce prices.

"We don't want to see Obama walk in and just play small ball again," says Cohen.

"Obama really needs to take this innovation problem on head on.” - SEE EDITORIAL P.577

\section{CORRECTION}

The News Feature 'Dynasty' (Nature 493, 286-289; 2013) wrongly stated that Peter Kareiva was a student of Bob Paine. Kareiva is in fact a friend of Paine's.

\section{CLIMATE TEAM CHANGE}

\section{Turnover at the top}

Even as US President Barack Obama vows action against climate change, he is expected to lose the leaders of three agencies with important stakes in environment issues. The names of possible replacements have begun to circulate, although none has been named officially.

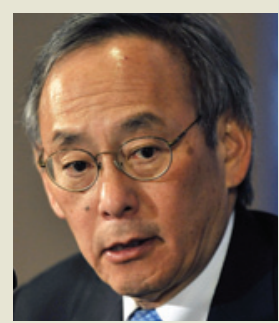

\section{DEPARTMENT OF ENERGY}

\section{Departing: Steven Chu}

In addition to overseeing US $\$ 37$ billion awarded to the department by the 2009 US stimulus package, Chu (pictured) restructured research at the energy agency, garnering political support for the high-risk, high-reward Advanced Research Projects AgencyEnergy, as well as for five Energy Innovation Hubs for integrated and applied research. The stimulus funding came under intense criticism from conservatives, especially the $\$ 535$ million that went to now-defunct solar-cell manufacturer Solyndra of Fremont,

California. But scientists and environmentalists are pushing for an expanded effort to nurture low-carbon technologies.

\section{Candidates: Byron Dorgan, Dan Reicher}

A former Democratic senator for North Dakota, Dorgan has three decades of congressional experience representing a state at the heart of the shale-oil boom, and has said that hydraulic-fracturing technologies, used properly, are safe. Reicher, an attorney by training, previously headed Google's \$1-billion initiative for investing in energy and climate, where he guided investments into solar technologies and electric transport. He served as the energy agency's assistant secretary for efficiency and renewable energy under former president Bill Clinton and was a staff member on then-president Jimmy Carter's commission to investigate the 1979 Three Mile Island nuclear accident in Pennsylvania.

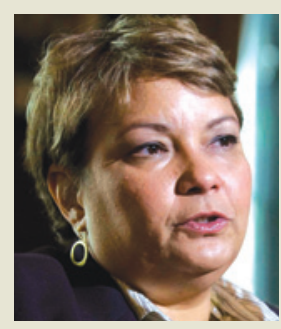

\section{ENVIRONMENTAL PROTECTION AGENCY}

\section{Departing: Lisa Jackson}

On entering office in 2009, Jackson (pictured) laid the groundwork for climate regulations by formally declaring carbon dioxide a dangerous pollutant. Since then, her agency has developed the first US greenhouse-gas standards for vehicles, tightened air-quality standards and proposed emissions limits for power plants. Her successor will lead efforts to take action on global warming by imposing new regulations on industry.

\section{Candidates: Christine Gregoire, Bob Perciasepe}

A former governor of Washington, Gregoire signed a 2010 law setting up greenhousegas reporting requirements and requiring state agencies to reduce emissions, but pulled Washington out of the Western Climate Initiative, a regional emissions-trading programme led by California. She has also been floated as a candidate to lead the Department of the Interior and the energy department. Perciasepe, currently deputy administrator at the environment agency, developed a watershed-protection programme while previously at the agency under Bill Clinton. Before joining the Obama administration, he was chief operating officer at the National Audubon Society, a conservation organization in New York.

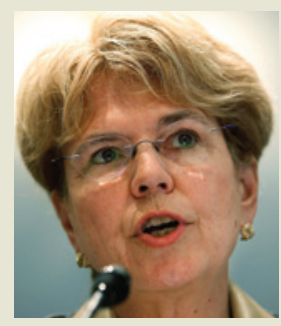

\section{NATIONAL OCEANIC AND ATMOSPHERIC ADMINISTRATION} Departing: Jane Lubchenco

Lubchenco (pictured) promoted a new US oceans policy and overhauled the way the agency disseminated environmental data. She encountered criticism for the handling of findings related to the Deepwater Horizon oil spill, and she was unable to sell the idea of a federal agency for climate services. Her successor will face questions about catch limits in ocean fisheries, and will need to resolve cost overruns and delays that have plagued weather- and climate-satellite programmes.

Candidate: Donald Boesch

A biological oceanographer, Boesch is currently president of the Center for Environmental Science at the University of Maryland in Cambridge, where he studies ecosystem management and climate change. He was a member of the White House commission that investigated the 2010 Deepwater Horizon oil spill. 